\title{
Oxyrhopus petolarius (Linnaeus, 1758) (Serpentes, Dipsadidae): Distribution extension and new departmental record for Paraguay
}

\author{
Hugo Cabral Beconi ${ }^{1,2 *}$ and Norman J. Scott ${ }^{3}$ \\ 1 Asociación Guyra Paraguay. Gaetano Martino 215, Asunción, Paraguay. \\ 2 Instituto de Investigación Biológica del Paraguay. Del Escudo 1607, Asunción, Paraguay. \\ 3 Research Associate, Smithsonian Institution. P.O. Box 307, Creston, CA, USA 93432. \\ ${ }^{*}$ Corresponding author. E-mail: huguitocabral@gmail.com
}

\begin{abstract}
We present the first record of Oxyrhopus petolarius for Departamento Itapúa, Paraguay. This record extends the species known distribution in approximately $166 \mathrm{~km}$ southwest from Puerto Bertoni in Departamento Alto Paraná, representing the southernmost record for the species and highlights the importance of protecting the remaining Atlantic Forest patches in Paraguay.
\end{abstract}

DOI: $10.15560 / 10.5 .1207$

Oxyrhopus petolarius (Linnaeus, 1758) is a medium size snake belonging to the tribe Pseudoboini (Zaher et al. 2009; Grazziotin et al. 2012) with an evident ontogenetic color change (Giraudo 2001). It is characterized by a black dorsum with anterior white and posterior red bands but with black snout, adults with iridescent black dorsum with reddish diffuse bands (not forming triads) and yellowish venter, 19/19/17 dorsal scales rows, 160-211 ventrals, and 81-101 subcaudal pairs (Giraudo 2001; MacCulloch et al. 2009; Lopez and Prado 2012). Often recorded under the name Oxyrhopus petola, after taxonomic revision Savage (2011) concluded that the correct name for the species is Oxyrhopus petolarius. The species has a broad distribution and is found southern Mexico, through Central America, and into South America (Bailey 1970; Lynch 2009; MacCulloch et al. 2009). At the east of the Andes, it is known to occur south to the northernmost extreme of Provincia Misiones in Argentina (Bailey 1970; Giraudo 2001; Giraudo and Scrocchi 2002; Lopez and Prado 2012). In Paraguay, O. petolarius is known only from records on its eastern border with Brazil (Cacciali 2009). Based on the previous records the species reaches its southernmost record in the state of Paraná in Brazil (Bérnils et al. 2007).

During a review of specimens housed in the Museo Nacional de Historia Natural del Paraguay (MNHNP), San Lorenzo, Paraguay, we found an overlooked specimen of Oxyrhopus petolarius which was collected $1 \mathrm{~km}$ northeast of the headquarters of the Centro de Mecanización Agrícola (CEMA), in Departamento Itapúa near to Pirapo city, on 21 September 1997 by Norman Scott, Lucy Aquino, Ismael Mora, and Oscar Romero, 26 $54^{\prime} 51^{\prime \prime}$ S, 55 $29^{\prime} 40^{\prime \prime} \mathrm{W}$, voucher MNHNP 11800. The specimen is a juvenile male, with the following measurements and characteristics: snout-vent length $31 \mathrm{~cm}$, tail length $9.3 \mathrm{~cm}, 203$ ventrals, and 98 paired subcaudals; $1 / 1$ preoculars; $2 / 2$ postoculars;
8/8 supralabials, four and five contacting the orbit; 10/10 infralabials, one to five contacting the chinshields; temporal plates $1+3 / 2+2$; dorsal scales $19 / 19 / 17$. The dorsum of head is mostly black in this preserved specimen, with only the temporals and supralabials six, seven, and eight being white; the infralabials and gular region are completely white, and a white nuchal collar 4 scales wide is present. The dorsal coloration of the body is black with 20 white bands; the black color does not reach the ventral region, which is completely white (Figures 1 and 2).

Oxyrhopus petolarius has been recorded twice in Paraguay, once in Puerto Bertoni (Academy of Natural Sciences of Philadelphia, Philadelphia, USA, voucher ANSP 32581), and also in the Itaipú complex of protected areas (Museo Ambiental de Itaipú, Hernandarias, Paraguay, vouchers MAI 61, 62, 81, and 94, without precise

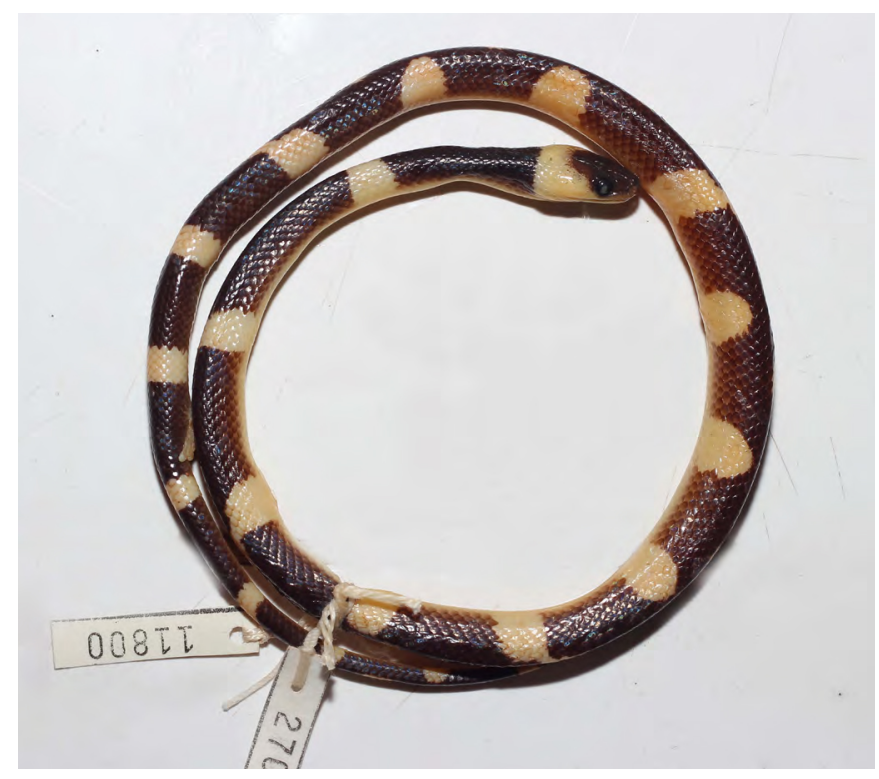

FIGURE 1. Dorsal view of Oxyrhopus petolarius (MNHNP 11800), Departamento Itapúa, Paraguay. 


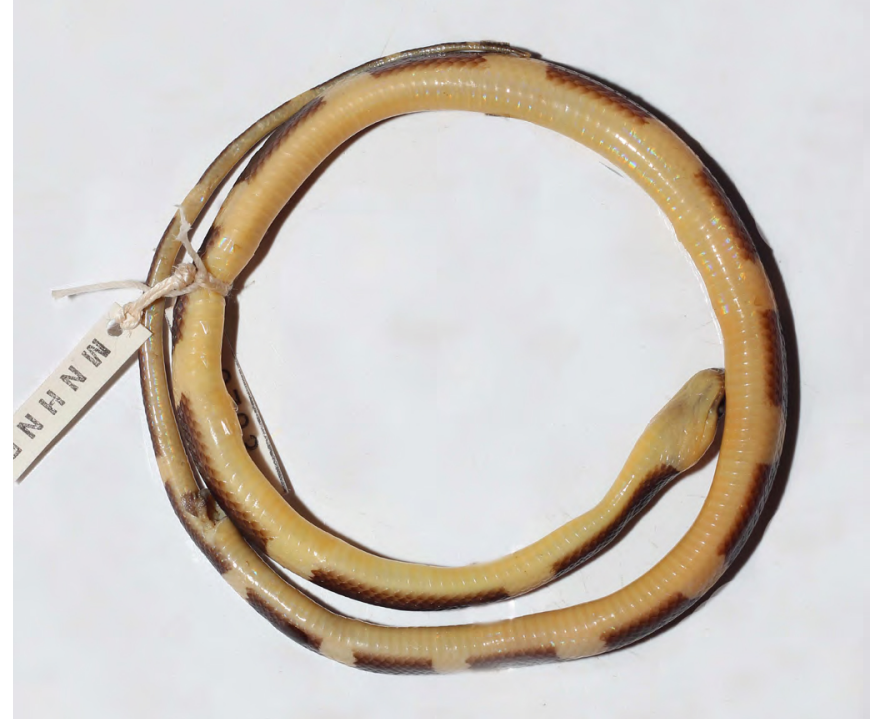

Figure 2. Ventral view of Oxyrhopus petolarius (MNHNP 11800), Departtamento Itapúa, Paraguay. locality data; Duré Rodas 1995). Both records are from Departamento Alto Paraná in extreme eastern Paraguay, near the Paraná river. Therefore, our new record is only the second with precise locality data from Paraguay, and the first in Departamento Itapúa; it extends the known distribution of the species about $165 \mathrm{~km}$ southwest of the nearest localities in Puerto Bertoni, Paraguay, and Provincia Misiones, Argentina (see Figure 3 and Giraudo 2001). Also, this is the new southernmost overall locality record for the species.

Oxyrhopus petolarius is an endangered species categorized as Vulnerable in Paraguay and Argentina (Motte et al. 2009; Giraudo et al. 2012) mainly because of the habitat destruction in both countries, and the increase of touristic development in Argentina (Cartes 2006; Giraudo 2012). Additionally, this specimen was found in the Atlantic Forest Ecoregion, which is considered a biodiversity hotspot that lost about $90 \%$ of its original forest cover (Myers et al. 2000; Mittermeier et al. 2004).

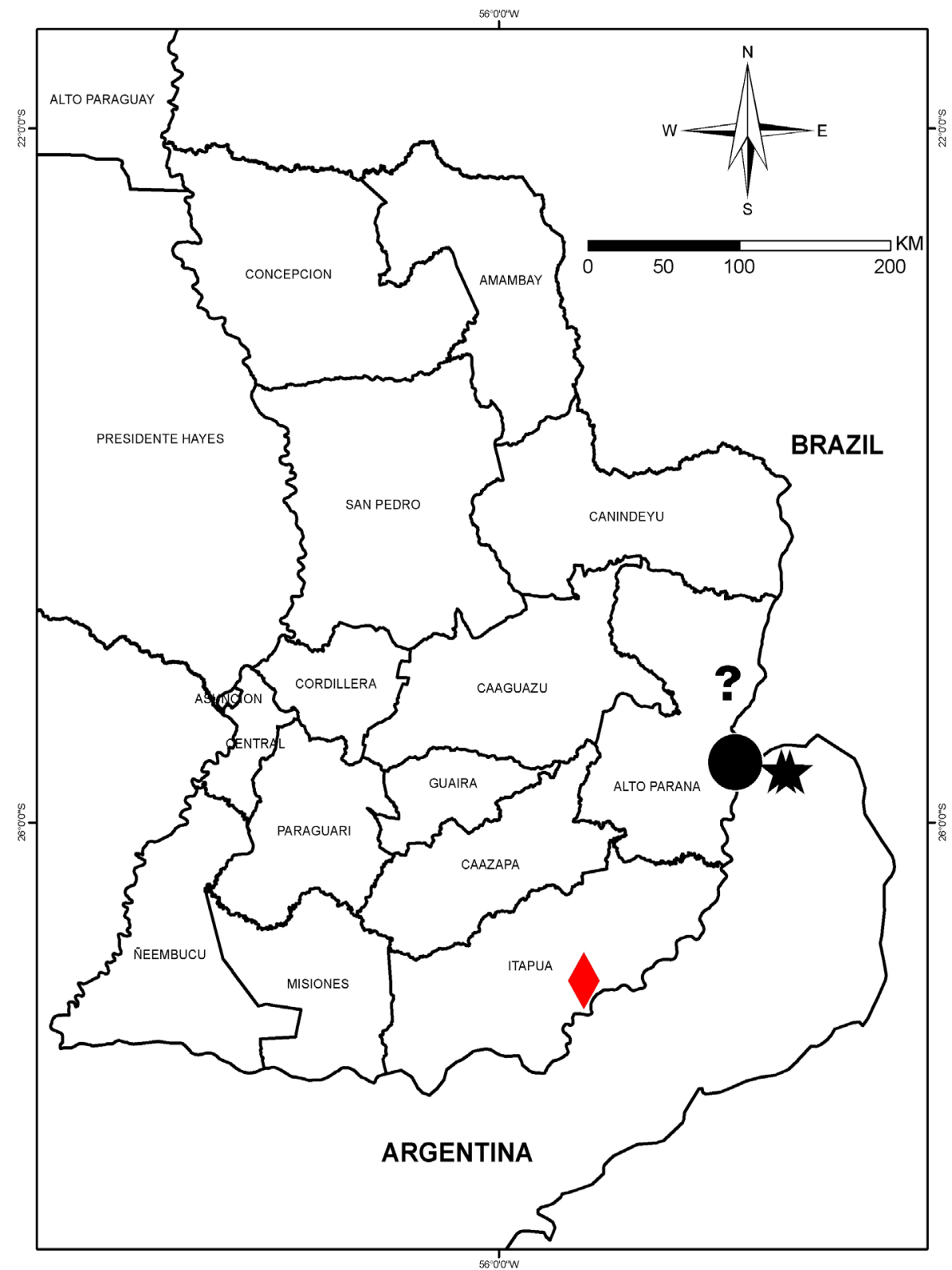

FIGURE 3. Map showing the southernmost records of Oxyrhopus petolarius Argentina and Paraguay and the new locality. The black stars are the records in Misiones, Argentina (Giraudo, 2001); the black circle is the Puerto Bertoni locality (ANSP 32581) in Paraguay; the question mark is the approximate locality for the Duré Rodas' (1995) record, and the red diamond represents the new record (MNHNP 11800), near Pirapo city, Departamento Itapúa, Paraguay. 
The few records of Oxyrhopus petolarius in Paraguay, and its limited known distribution in the area, highlights the importance of protecting the remaining Atlantic Forest patches in Paraguay.

ACKNOWLEDGEMENTS: We thank Martha Motte (MNHNP) for allowing access to specimens under her care and to Marianela Velilla and Sergio Rios for reviewing the manuscript, also to Nicolas Martinez for the photo of the specimen and Andrea Ferreira for processing the photographs. Also, we thank suggestions and corrections of Davi Lima Pantoja, Renan Janke Bosque, and one anonymous referee.

\section{Literature Cited}

Bailey, J.R. 1970. Oxyrhopus; pp. 229-235, in: J. Peters and B. OrejasMiranda (eds.). Catalogue of the Neotropical Squamata: Part I. Snakes. Bulletin of U. S. National Museum 297 (http://www. biodiversitylibrary.org/page/7868973).

Bérnils, R.S., A.R. Giraudo, S. Carreira and S.Z. Cechin. 2007. Répteis das porções subtropical e temperada da região Neotropical. Ciência $e$ Ambiente 35: 101-136.

Cacciali, P. 2009. Guía Para la Identificación de 60 Serpientes del Paraguay. Asunción: Asociación Guyra Paraguay. 218 pp.

Cartes, J.L. 2006. Breve historia de la conservación en el bosque Atlántico; pp. 37-54, in: J.L. Cartes (ed.). El Bosque Atlántico en Paraguay, Biodiversidad, Amenazas y Perspectiva. State of Hotspots Series. Asunción. Guyra, Paraguay: Conservation International - Center for Applied Biodiversity Science.

Duré Rodas, A. 1995. Estudio de reptiles y anfibios. Biota 2: 20-24.

Giraudo, A. 2001. Serpientes de la Selva Paranaense y del Chaco Húmedo. Buenos Aires: Literature of Latin America. 285 pp.

Giraudo, A. and G. Scrocchi. 2002. Argentinian snakes: An annotated checklist. Smithsonian Herpetological Information Service 132: 1-53 (https://repository.si.edu/bitstream/handle/10088/845/2002. SHIS132.pdf?sequence=1\&isAllowed =y)

Giraudo, A. 2012. Oxyrhopus petola (Linnaeus, 1758). Falsa Coral; pp. 357-358, in: Categorización del estado de conservación de la herpetofauna de la República Argentina. Ficha de los taxones. Serpientes. Cuadernos de Herpetología 26(1) (http://www.scielo.org. ar/pdf/cherp/v26s1/v26s1a04.pdf).

Giraudo, A.R., V. Arzamendia, G.P. Bellini, C.A. Bessa, C.C. Calamante, G. Cardozo, M. Chiaraviglio, M.B. Constanzo, E.G. Etchepare, V. Di Cola, D.O. Di Pietro, S. Kretzchmar, S. Palomas, S.J. Nenda, P.C. Rivera, M.E. Rodríguez, G.J. Scrocchi and J.D. Williams. 2012. Categorización del estado de conservación de las serpientes de la República
Argentina. Cuadernos de Herpetología 26(1): 303-326 (http://www. scielo.org.ar/pdf/cherp/v26s1/v26s1a04.pdf).

Grazziotin, F.G., H. Zaher, R.W. Murphy, G. Scrocchi, M.A. Benavides, Y. Zhang and S.L. Bonato. 2012. Molecular phylogeny of the New World Dipsadidae (Serpentes: Colubroidea): a reappraisal. Cladistics 28(5): 437-459 (doi: 10.1111/j.1096-0031.2012.00393.x)

Lopez, A. and W. Prado. 2012. Anfibios y reptiles de Misiones. Buenos Aires: Grafica Pinter S.A. 97 pp.

Lynch, J.D. 2009. Snakes of the genus Oxyrhopus (Colubridae: Squamata) in Colombia: taxonomy and geographic variation. Papéis Avulsos de Zoologia 49(25): 319-337 (http://www.scielo.br/pdf/paz/v49n25/ v49n25.pdf).

MacCulloch, R.D., A. Lathrop, P.J.R. Kok, R. Ernst and M. Kalamandeen. 2009. The genus Oxyrhopus (Serpentes: Dipsadidae: Xenodontinae) in Guyana: morphology, distributions and comments on taxonomy. Papéis Avulsos de Zoologia 49(36): 487-495 (http://www.scielo.br/ pdf/paz/v49n36/v49n36.pdf).

Mittermeier, R.A., P. Robles, M. Hoffman, J. Pilgrim, T. Brooks, C.G. Mittermeier, J. Lamoreux and G. da Fonseca. 2004. Hotspots Revisited. Earth's Biologically Richest and Most Endangered Terrestrial Ecoregions. Ciudad de Mexico: CEMEX. 390 pp.

Motte, M., K. Nuñez, P. Cacciali, F. Brusquetti, N. Scott and A.L. Aquino. 2009. Categorización del estado de conservación de los anfibios y reptiles de Paraguay. Cuadernos de Herpetología 23(1): 5-18 (http:// www.scielo.org.ar/pdf/cherp/v26s1/v26s1a04.pdf)

Myers, N., R.A. Mittermeier, C.G. Mittermeier, G. da Fonseca and J. Kent 2000. Biodiversity hotspots for conservation priorities. Nature 403: 853-858 (doi: 10.1038/35002501).

Savage, J. M. 2011. The correct species-group name for an Oxyrhopus (Squamata: Dipsadidae) variously called Coluber petalarius, C. pethola, C. petola, or $C$. petolarius by early authors. Proceedings of the Biological Society of Washington 124(3): 223-225 (doi: 10.2988/1106.1).

Zaher, H., F. G. Grazziotin, J. E. Cadle, R. W. Murphy, J. C. de Moura-Leite and S. L. Bonatto. 2009. Molecular phylogeny of advanced snakes (Serpentes, Caenophidia) with an emphasis on South American xenodontines: A revised classification and descriptions of new taxa. Papéis Avulsos de Zoologia 49(11): 115-153 (http://www.scielo.br/ pdf/paz/v49n11/a01v49n11.pdf).

RECEIVED: January 2014

ACCEPTED: September 2014

PuBlished ONLINE: October 2014

EDITORIAL RESPONSIBILITY: Davi Pantoja 